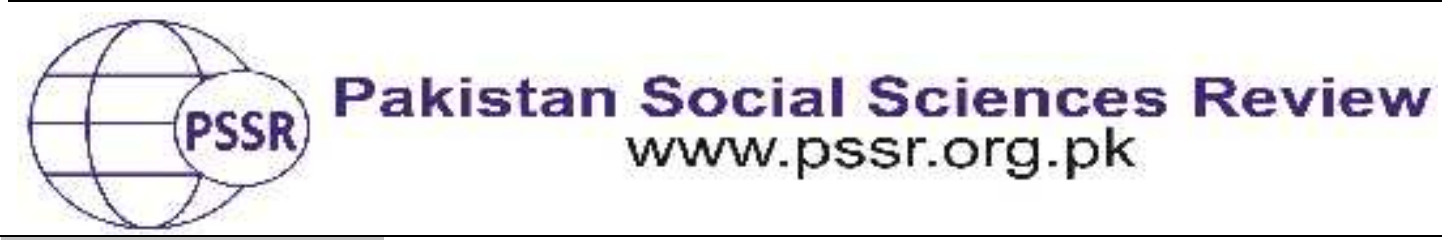

RESEARCH PAPER

\title{
Effect of Constructivist Teaching Approach on Student's Achievement in Science at Elementary Level
}

\author{
Dr. Ghazala Noureen ${ }^{1}$ Tahseen Arshad ${ }^{2}$ Muqadas Bashir ${ }^{3}$
}

1. Associate Professor, Department of Education, Lahore College for Women University, Lahore Pakistan

2. Lecturer, Department of Education, Lahore College for Women University, Lahore Pakistan

3. MS Scholar, Department of Education, Lahore College for Women University, Lahore Pakistan

\begin{tabular}{|c|c|}
\hline PAPER INFO & ABSTRACT \\
\hline $\begin{array}{l}\text { Received: } \\
\text { July } 29,2020 \\
\text { Accepted: } \\
\text { September } 05,2020 \\
\text { Online: } \\
\text { September } 30,2020\end{array}$ & $\begin{array}{l}\text { Main objective of this study is to determine the effect of this } \\
\text { approach while comparing it with traditional method of } \\
\text { teaching. The study was experimental in nature. The population } \\
\text { of study was } 7 \text { th class students school. Sixty students were } \\
\text { selected randomly. After pretesting students were distributed }\end{array}$ \\
\hline $\begin{array}{l}\text { Keywords: } \\
\text { Constructivist } \\
\text { Teaching, } \\
\text { Achievement, } \\
\text { Elementary } \\
\text { Level }\end{array}$ & $\begin{array}{l}\text { into two groups. Treatment was assigned randomly to the } \\
\text { groups. Experimental group was taught through constructive } \\
\text { approach and control group was taught through traditional } \\
\text { approach. Treatment time was 8-weeks. Selected topics of } \\
\text { science were taught to both groups. An achievement test was } \\
\text { constructed and validity and reliability of the test was ensured }\end{array}$ \\
\hline Corresponding & $\begin{array}{l}\text { through expert opinion and pilot testing. Conquest } 4 \text { was used } \\
\text { to determine psychometric properties of items based on IRT. }\end{array}$ \\
\hline een@yah & $\begin{array}{l}\text { Selected items were used in achievement test. After taking post- } \\
\text { test independent t-test was used to calculate the difference } \\
\text { between two groups. The main findings of the research } \\
\text { indicated that there is a significant difference between } \\
\text { achievements of two groups. Experimental group performance } \\
\text { is better as compare to traditional method. So, it would be } \\
\text { suggested that as constructivism renovates the student from a } \\
\text { passive learner to an active participant in the teaching learning } \\
\text { process, teacher's role is to facilitate students in constructing } \\
\text { knowledge rather just mechanically consuming knowledge from } \\
\text { the teacher or the textbook. }\end{array}$ \\
\hline
\end{tabular}

\section{Introduction}

Some core ideas of constructivism are mainly influenced by Swiss psychologist and epistemologist Jean Piaget (1896-1980). Starting from his early 
writing to his last publication, he remained loyal to his stance on constructivist perspective. Educationist deeply focused on Piaget's stage theory and tried to implement the intellectual development stages in educational setting. This endeavor of matching remained influential in educational setting for a long period (Sjoberg, 2010).

As pointed out in previous paragraph that constructivism developed from a Piagetian perspective, and later on some other theorist enters and tried to relate intellectual development with social and cultural conditions mandatory for learning. One of the Piaget's contemporary is Russian Lev Vygotsky (1896-1934) who laid emphasis on social and cultural aspects in the process of language learning. Because of more stress on the social and cooperative aspect of learning, he is called as a father of social constructivism, on the other side Piaget is considered as a father of cognitive constructivism.

Applications of social constructivism are most commonly initiated in schools recently through the use of cooperative and collaborative teaching methodologies (Jones \& Brader-Araje, 2000). The significant contribution of constructivism's perspectives is its emphasis on construction of meaning by the learner through his/her experience. Active participation of the learner in learning process is more appealing for educators. Through social cooperation learners continually check their postulates and create new information by précising the previous knowledge. Constructivism acknowledged the role of prior learning, distinguishing that learners are not blank slates or empty vessels waiting to be filled with knowledge. Rather students construct new knowledge on a rich array of previous experiences, knowledge, and beliefs. Students are dynamic information earpiece(Khan, 2019; Jones, Carter, \& Rua, 1999). This prior knowledge is significant and called schema. All knowledge is passed through existing schema and when students are actively involved in learning rather than passive members learning become more efficient as stated by constructivist (Chowudry, 2016; Azeem \& Khalid, 2012). "The central principles of this approach are that learners can only make sense of new situations in terms of their existing understanding. Learning involves in active process of learning in which learners construct meaning by linking new ideas with their existing knowledge" (Naylor \& Keogh, 1999, p.93).That's why every student has its own interpretation of knowledge according to their mental capability (Learning Theories Knowledgebase, 2008).Constructivist said that human world is different from world of fantasy so they learn accordingly (Chowudry,2016).Learners curiosity about how things work in real word triggered by constructivism (Azeem \& Khalid, 2012). Relatively, knowledge is constructed by learners, they construct knowledge through active and cognitive process of development; they are the maker and creators of important knowledge (Mir \& Jain, 2015).

Understanding of new knowledge depends upon assimilations and accommodations capacity of human beings. Learning occurs when student make use of previous knowledge and experience. Thus, manifold explanations of an incident 
are possible and these multiple explanations are source of creativity in learners. A constructivist believes that students require time to reflect on their experiences to assimilate and accommodate it with what they already know. After this become enable to understand new phenomenon (Khan, 2019; Thompson, 2018; Bada,2015).

According to Mir and Jain (2015) "Constructivist teaching fosters critical thinking and creates active and motivated learning. A constructivist approach frees teachers to make decisions that will boost and improve learner's development it means constructivist classroom not only benefits learning of students, but it also helps to increase the various ability among learners, such as: problem-solving ability, scientific attitude, fostering creativity, decision power making ability, reflective ability, higher order thinking ability and many more" (pp 362).

Process of learning is more significant than the product of learning as per constructivist approach. Role of learner as an active recipient is emphasized. It depends on learner how he/she learns new knowledge. This type of learning requires flexible classrooms and learner should have freedom to participate in different activities to construct new knowledge (Gomleksiz \&Elaldi, 2011;Amineh\&Asl, 2015; Jaleel \& Verghis, 2015;Kamphorst, 2018).

Teaching in constructive classroom is to guide students to grasp the concepts and formulate opportunities for learners to rethink and build new concepts by understanding misunderstandings; teachers ask questions from students to encourage and engage them and corroborate them in research to challenge current concepts. In constructive classroom, teacher play passive role just guide students and lead them by providing instructions and ideas to create new learning situations to active students of science. Constructivism has many models for learning experiences of students but the 5 E's model by Roger Bybee is best for implementation in science classroom because it formulate under the Biological science curriculum study (BSCS) project. The 5 'Es' stand for Engage, Explore, Explain, Elaborate and Evaluate. That's why constructive approach emphasizes learning by process of demonstration, group work, analyze problems, self-assessment and other methods such as taking review from peers rather than using learning in result of consequences (Ayaz,2015; Caliskan,2015;Singh,2015).

Due to the above mention reason many countries understand the need and change their educational system from traditional to constructivist learning methodology. Pakistan education is still following traditional mode of teaching and learning. Keeping in view the importance of this approach for student's conceptual understanding, present study is designed to know empirically the effect this approach on student's achievement in Pakistani context.

\section{Material and Methods}

The main objective of this experimental research was to explore the effect of constructivist teaching approach on student's achievement in science at grade VII. For present study quantitative research approach under the umbrella of positivistic 
paradigm was used. Experimental method was to investigate phenomenon under study. Pretest and post-test design was used. The main foundation of pretestposttest design consists of obtaining the outcome of interest after conducting some treatment, followed by posttest on the same sample set after treatment.

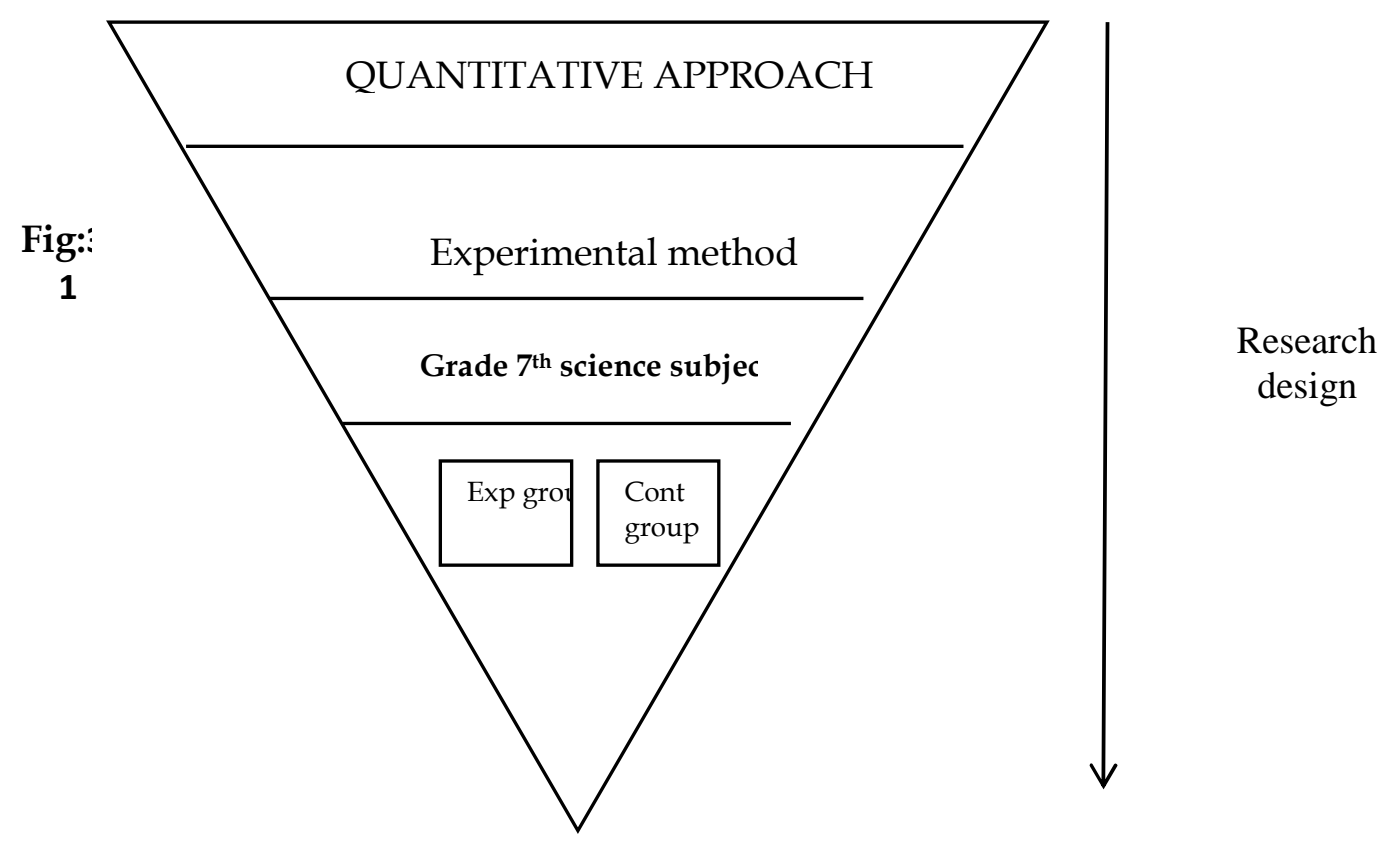

All the $7^{\text {th }}$ class students studying in a local school were the population of the study. There were 360 students distributed in 6 sections (60 students in each section). One of the sections is selected randomly. After pretest, students were distributed in to two groups (30 students in each group). Treatment was also randomly assigned. Group taught through constructivist approach is called experimental group and group taught through traditional method is called control group.

Science achievement test was constructed by using the mathematical framework of National Assessment of Educational Progress (NAEP) and national curriculum of Pakistan for grade 7. Items were constructed and aligned to the science framework. Three aspects of Bloom's taxonomy were covered (knowledge, understanding and application). Test was content validated through expert opinion (8 experts). Instrument was pilot tested on 500 hundred students to ensure the reliability of the test. The data from pilot test was analyzed by using Conquest 4 software to determine psychometric properties of the test (IRT model fit indices). 40 items were selected that fulfilled the criteria. Lesson plans were developed for both method and both groups were taught for eight weeks. 


\section{Results and Discussion}

Data were collected while administering achievement test and test was used to test following hypotheses.

Hypothesis 1: There is no significant difference between achievement score of experimental and control groups in pretest.

Table 1

Comparison Between experimental group and control group- on the basis of Pretest by t-test

\begin{tabular}{ccccccc}
\hline GROUPS & N & MEAN & STD.DEV & T & DF & $\begin{array}{c}\text { SIG. } \\
\text { (2-TAILED) }\end{array}$ \\
\hline Experimental & 30 & 10.27 & 2.867 & & & \\
\hline Control & 30 & 9.00 & 2.613 & 1.785 & 58 & .079 \\
\hline
\end{tabular}

Table 1 indicates that experimental group and control group are not significantly different and the value of $\mathrm{t}$ is 1.785 which is smaller than the critical value $1.96(\mathrm{df}=58)$ at 0.05 level of significance. Similarly, value of $p$ is $.079>0.05 .50$, it indicates that null hypothesis showing there is no significant difference between pretest achievement score of experimental and control groupwas accepted. This revealed that both groups were equal before treatment.

Hypothesis 2: There is no significant difference between experimental and control groups post test scores.

Table 2

Comparison Between experimental group and control group on the basis of posttest by t-test

\begin{tabular}{ccccccc}
\hline GROUPS & N & MEAN & STD.DEV & T & DF & $\begin{array}{c}\text { SIG. } \\
\text { (2-TAILED) }\end{array}$ \\
\hline Experimental & 30 & 17.63 & 2.498 & & & \\
\hline Control & 30 & 13.10 & 3.284 & 6.018 & 58 & .000 \\
\hline
\end{tabular}

Table 2 indicates that experimental group and control group are significantly different and the value of $t$ is 6.018 which is greater than the critical value $1.96(\mathrm{df}=$ 58 ) at 0.05 level of significance. Similarly, value of $p$ is $.000<0.05$. This show that null hypothesis stated there is no significant difference between post-test achievement score of experimental group and control group was rejected. Table concludes that students of experimental group are showing significantly better results than control group after treatment in post-test.

\section{Discussion}

Teachers who used constructivist activities in the classroom empower the learners to experience new things and enhance their understanding on the basis of prior knowledge. Piaget and Vygotsky's is earliest proponent of constructivism. 
Later on, in 1970's educators focused on this approach and it became one of the prominent students centered approach in teaching and learning environment. Some advance countries Like USA and UK revamp their curriculum as per need of this approach. In USA, a center was established and numerous researches were conducted and many projects were designed to establish the effectiveness of this approach. It was established that effectiveness of this approach depends upon teachers' understanding of constructivist theory, principles and pedagogy. Metaanalysis was conducted by Gunduz and Hursena (2015) to investigate the development and the inclination of researches in the field of constructivism in teaching. It was found during this investigation that 161 were articles published between 2002 and 2013 in Science Direct, Eric and EBSCO are examined. There are three publications in 2002 and become 43 till 2012 and 10 studies published in 2013.Analysis revealed that constructivist approach is a contemporary trend in teaching and learning and is gaining importance. This approach is student centered and the role of the student is active recipient of information. Like, wise role of the teacher is described as a facilitator in teaching learning process (Ozcan, Gunduz, Danju, 2013).

Most of the study shows English language is the major area constructivist approach was used in research studies. Teaching of science is another area where this approach is extensively used. Present study is also focusing on teaching of science through this approach. Another mata-analysis was conducted by Ayaz (2015) in Turkish context. The aim of the study was to determine the effect of constructive approach on the academic achievement of the students. It was found that 53 studies were conducted to find the out effects of constructivist learning approach on students' academic achievement. Total number of participants were 3271 (control group and the experimental group). It is revealed during data analysis that 50 out of 53 study results indicate positive effect of constructivist approach on student's achievement. Only three studies showed negative effect. Findings of the present study are congruent with above studies. Finding of this study also showed positive effect of this approach on student's achievement. Another important finding reported in literature is that this approach is more effective for teaching of science.

In Pakistan, constructive learning strategy in classroom is not very common and main focus of teaching is rote memorization. In Pakistan science is considered as a subject who mostly taught trough simple lecture method. It was a different experience for group of students, taught through that approach. Keeping in view, it's necessary to teach the subject according to its need by adopting new and modern methods of teaching. The novelty of this method makes students more attentive and motivated. 


\section{Reference}

Amineh, R. J., \&Asl, H. D. (2015). Review of constructivism and social constructivism. Journal of Social Sciences, Literature, and Languages, 1(1), 9-16.

Ayaz, M. F., \& Şekerci, H. (2015). The Effects of the Constructivist Learning Approach on Student's Academic Achievement: A Meta-Analysis Study. The Turkish Online Journal of Educational Technology, 14(4).

Chowdhury, S. R. (2016, February). A Study On The Effect Of Constructivist Approach On The Achievement In Mathematics Of IX Standard Students. IOSR Journal of Humanities And Social Science, 21(2),35-40. doi:10.9790

Gomleksiz, M. N., \& $\quad$ Elaldi, Ş. $\quad$ (2011). YapılandırmacıYaklaşımBağlamındaYabancıDilÖğretimi. Electronic Turkish Studies, 6(2).

Gunduz, N., \&Hursena, C. (2016). Constructivism in Teaching and Learning; Content Analysis Evaluation. Cyprus Procedia - Social And Behavioral Sciences, 228, 1-2. doi: 10.1016

Jaleel, S., \& Verghis, A. M. (2015). Knowledge creation in constructivist learning. Universal Journal of Educational Research, 3(1), 8-12.

Jones, M., \&Araje, L. (2002). The Impact of Constructivism on Education: Language, Discourse, and Meaning. American Communication Journal, 5(3).

Jones, M. G., Carter, G., \& Rua, M. (1999). Exploring the development of conceptual ecologies: Communities of concepts related to convection and heat. Journal of Research in Science Teaching, 37, 139- 159.

Kamphorst, J. C. (2018). Multidisciplinary Cooperation by Students in a European University of Applied Sciences. Journal of University Teaching and Learning Practice, 15(1), 5.

Mir,M.,\&Jain,D.(2015).Constructivism: A Complete Teaching and Learning Approach.International Journal Of Scientific Research, 4(11), 362-363.

Ozcan, D. Gunduz,N. Danju, I.2013). The Attitudes of High School Teachers towards Contemporary Educational Approaches and Theories. Cypriot Journal of Educational Sciences, 8(3), 341-350.

Sjøberg, S. (2010). Constructivism and Learning. International Encyclopedia Of Education, 5, 458-490.

Sharma, C. (2019). Educational Aspirations Among Secondary School Students In Relation to Their Perceived Parental Encouragement. Scholarly Research Journal For Interdisciplinary Studies, 6(51), 12599-12608. 
Thompson, Penny. (2018). Foundations of educational technology. https://epress.library.okstate.edu/catalog/foundations-of-educational technology/foundationsof-educational-technology-2018.pdf 